\title{
Quantification of serum hepatitis C virus core protein level in patients chronically infected with different hepatitis $\mathrm{C}$ virus genotypes
}

E Orito, M Mizokami, T Tanaka, J Y-N Lau, K Suzuki, M Yamauchi, Y Ohta, A Hasegawa, S Tanaka, M Kohara

Second Department of Medicine,

Nagoya City University

Medical School,

Nayoya, Japan

E Orito

M Mizokami

K Suzuki

M Yamauchi

Liver Unit,

The Tokyo

Metropolitan

Komagome Hospital,

Tokyo, Japan

T Tanaka

$S$ Tanaka

Section of

Hepatobiliary

Diseases,

Department of

Medicine,

University of Florida,

Gainesville,

Florida, USA

J Y-N Lau

International Reagents Corporation,

Kobe, Japan

Y Ohta

Corporate Research \& Development

Laboratory,

Tonen Co,

Saitama, Japan

A Hasegawa

Department of

Microbiology,

The Tokyo

Metropolitan Institute

of Medical Science,

Japan

M Kohara

Correspondence to:

Dr M Mizokami,

Second Department of

Medicine

Nagoya City University

Medical School

1 Kawasumi,

Nagoya 467, Japan.

Accepted for rapid

publication
15 October 1996
Abstract

Background/Aim-A novel fluorescent enzyme immunoassay (FEIA) for the detection and quantification of serum hepatitis C virus (HCV) core protein was developed. The aim of this study was to evaluate the relation among serum HCV core protein level, HCV RNA level, and HCV genotype in patients with chronic HCV infection.

Patients and Methods-Serum HCV core protein, HCV RNA, HCV genotype were determined in 175 patients using the FEIA, branched DNA-assay (Quantiplex HCV RNA ver $1 \cdot 0$ ), and serologically defined genotyping assay, respectively. For the specificity, all 13 patients seronegative for anti-HCV were negative for serum core antigen and HCV RNA by FEIA and bDNA, respectively.

Results-FEIA assay seems to be more sensitive than bDNA for patients with HCV type 2 infection (detection: 83.4\% $v$ $63 \cdot 4 \%, \mathrm{p}<0 \cdot 01$ ). There was a good overall correlation between the FEIA and bDNA results. However, when the patients were stratified into their HCV types, a correlation was observed in HCV type 1 but not in type 2 infection. Patients with HCV type 2 infection had a lower serum HCV core protein level (median 56 RFI) compared with type 1 infection (median 149 RFI, p<0.01). Thirty seven patients subsequently received interferon $\alpha$ therapy, patients who showed a complete and sustained response had a lower pretreatment serum HCV core protein level compared with patients who had a relapse and nonresponders (36 $v 338 \mathrm{RFI}, \mathrm{p}<0 \cdot 01$ ).

Conclusions-This study showed that FEIA (1) is a good assay for the detection and quantification of serum $\mathrm{HCV}$ core protein level, (2) is also very sensitive in detecting HCV core protein in patients with HCV type 2 infection, and (3) may have a role as a predictor of subsequent response to interferon therapy.

(Gut 1996; 39: 876-880)

Keywords: HCV core protein, fluorescent enzyme immunoassay (FEIA), HCV viraemia, HCV genotype, bDNA.

Hepatitis C virus (HCV) is believed to be a member of flavivirus family and has a single strand, positive-sense RNA genome, which is believed to couple with core protein to form the core particle covered by an envelope. ${ }^{1-3}$ Because of the low level of circulating $\mathrm{HCV}$ particles and the lack of an easily available cell culture or small animal models, direct detection of $\mathrm{HCV}$ by conventional techniques was deemed difficult, if at all possible at the present time. So far, diagnosis of $\mathrm{HCV}$ infection has relied on the detection of antibody to $\mathrm{HCV}$, an indirect evidence for exposure to this viral agent. ${ }^{4-5}$ Detection of HCV genome was made possible with the highly sensitive reverse transcription polymerase chain reaction (RT-PCR), ${ }^{6}$ and recently, by the branched DNA signal amplification assay (bDNA). ${ }^{7}$ To elucidate the significance of $\mathrm{HCV}$ viraemia in relation to disease profile, pathobiology, and as a predictor of response to interferon $\alpha$ (IFN) therapy, quantification assays are necessary, and techniques based on PCR (for example, competitive PCR) or bDNA are used by various investigators to measure $\mathrm{HCV}$ viraemia level. ${ }^{78}$ With these assays, the clinical and pathobiological implications of $\mathrm{HCV}$ viraemia have been extensively investigated. ${ }^{8-11}$ However, with the availability of more $\mathrm{HCV}$ genomic sequences, it becomes obvious that even the highly conserved regions of $\mathrm{HCV}$ genome do vary. As a result, the quantitative bDNA assay was found to underestimate HCV type 2 and 3 RNAs. ${ }^{12}{ }^{13}$ Newer molecular biology based assays that can tackle this problem have been designed and hopefully may solve this technical issue.

Recently, a novel assay for the quantification of serum $\mathrm{HCV}$ core protein was described. As core proteins are contained within the viral particle, serum levels of $\mathrm{HCV}$ core protein should reflect $\mathrm{HCV}$ viraemia. This fluorescent enzyme immunoassay (FEIA) is based on the capture and detection of $\mathrm{HCV}$ core protein by two highly affinity monoclonal antibodies. ${ }^{14}$ Based on nucleotide sequence comparison, these two antibodies were directed to the conserved regions of the $\mathrm{HCV}$ core protein. The aim of this study was to determine the applicability of this assay in patients infected with different $\mathrm{HCV}$ genotypes. In those patients who subsequently received IFN therapy, pretreatment $\mathrm{HCV}$ core protein level in relation to subsequent response to IFN was also assessed. 


\section{Methods}

\section{Patients}

A total of 175 patients (male: female $=100: 75$, age $=($ mean $(\mathrm{SD})) \quad 56.7(12 \cdot 4)$ years $)$ seropositive for antibody to $\mathrm{HCV}$ (anti-HCV, second generation enzyme immunoassay, Ortho Diagnostics, Raritan, NJ) were prospectively studied. All patients were seronegative for hepatitis B virus surface antigen (radioimmunoassay, AUSRIA 2, Abbott Laboratories, North Chicago, IL). Liver histology confirmed chronic hepatitis $(\mathrm{CH})$ in 84, liver cirrhosis (LC) in 37, and the remaining 54 patients were found to have hepatocellular carcinoma (HCC) based on clinical and biochemical information, serum $\alpha$ fetoprotein levels, radiological findings and in 41 patients, also confirmed by liver histology. In all samples seropositive for anti-HCV, HCV RNA were detected by RT-'nested' PCR with primers derived from the highly conserved 5'untranslated region. ${ }^{6}$ Thirteen patients seropositive for $\mathrm{HBsAg}$ and seronegative for antiHCV (male:female=9:4; age 45.8 (11.9) years) were recruited as liver disease controls (liver histology: $\mathrm{CH}$ in five, LC in five, and HCC in three).

All serum samples were prospectively collected at outpatient clinics and were prepared, aliquoted, and stored at $-80^{\circ} \mathrm{C}$ within two hours. This method has been previously shown to best preserve HCV RNA, and possibly, viral particles. ${ }^{15}$

Of the 84 patients with $\mathrm{CH}, 37$ were subsequently treated with lymphoblastoid IFN (Sumiferon, Sumitomo Pharmaceuticals, Japan), six million unit (MU) daily for two weeks followed by six MU thrice weekly for 22 weeks (468 MU in total). The use of IFN was approved by our local institutional review board and a written informed consent was obtained from all patients according to standard guidelines. Complete and sustained response was defined as sustained normalisation of serum alanine aminotransferase (ALT) during treatment and for the entire follow up period (at least 12 months) after cessation of IFN therapy. The other patients, including patients who relapsed after a complete response and patients showing no or partial response, were defined as non-responders.

\section{Quantification of serum HCV core protein level by FELA}

Serum HCV core protein level was measured by sandwich FEIA using the monoclonal antibody $5 \mathrm{~F} 11$ (recognising an epitope within amino acid 41-60) for solid phase capture and another monoclonal antibody 5E3 (epitope within 21-40) conjugated with $\beta$-D-galactosidase as a reporter. ${ }^{14}$ Briefly, to $200 \mu l$ serum sample, $40 \mu \mathrm{l}$ of $25 \%$ polyethylene glycol 4000 (PEG4000) was added and incubated for one hour at $4^{\circ} \mathrm{C}$. The precipitant was obtained by centrifugation, dissolved in $50 \mu$ l of $0.5 \mathrm{M}$ $\mathrm{NaCl}$ and $0.5 \mathrm{M}$ sodium citrate, and denatured with $50 \mu l 0.5 \mathrm{M} \mathrm{NaOH}$ for 30 minutes at $37^{\circ} \mathrm{C}$. These pretreated samples were added and incubated for 10 minutes in the EIA well coated with the monoclonal antibody $5 \mathrm{~F} 11$ for 10 minutes. After washing with wash buffer, monoclonal antibody $5 \mathrm{E} 3$ conjugated to $\beta$ $D$-galactosidase was added for nine minutes at $37^{\circ} \mathrm{C}$ to trace $\mathrm{HCV}$ core protein. The substrate used was $0.1 \mathrm{mM}$ 4-methylumbelliferyl $\beta-\mathrm{D}$ galactopyranoside and this was incubated for nine minutes at $37^{\circ} \mathrm{C}$. The relative fluorescence intensity (RFI) was measured by a fluorometer at $360 \mathrm{~nm}$ for excitation and $450 \mathrm{~nm}$ for emission. The cut off value of this assay was previously determined to be less than $20 \mathrm{RFI}$.

\section{Serum HCV RNA level and HCV genotype determination}

Serum HCV RNA level was measured quantitatively by bDNA (Quantiplex-HCV RNA, Ver 1.0, Chiron, Emeryville, CA).$^{8}$ The cut off value of this assay was 0.35 million genome equivalent $/ \mathrm{ml}(\mathrm{Meq} / \mathrm{ml})$. Recently, it was shown that HCV RNA level in patients with $\mathrm{HCV}$ type 2 infection requires a correction factor of 3 to give a better estimation of HCV RNA. ${ }^{13}$ Accordingly, the viraemia level in these patients were adjusted according to this recommendation.

Serologically defined $\mathrm{HCV}$ genotype (HCV type) was determined by enzyme immunoassay into HCV type 1, 2, mixed type (type 1 and 2) and indeterminate type as previously described. ${ }^{16}$ The nomenclature of HCV genotype was based on the system proposed by Simmonds et al. ${ }^{17}$

\section{Statistics}

Categorical data were analysed with Fisher's exact test. The Mann-Whitney non-parametric rank sum test and Student's $t$ test were used where appropriate. Discriminant analysis was used for multivariate analysis.

\section{Results}

Of the 175 patients seropositive for anti-HCV, $129(73 \cdot 7 \%)$ had HCV type $1,31(17 \cdot 7 \%)$ type $2,3(1 \cdot 7 \%)$ mixed type (type 1 and 2 ), and 12 (6.9\%) indeterminate HCV genotype. There was no significant difference in sex, age, history of transfusion, estimated duration of infection, serum ALT level between patients with different HCV types (Table I).

To evaluate the reproducibility of this $\mathrm{HCV}$ core protein assay, three positive standard samples with the low, middle and high HCV core protein level were measured, respectively (Table II). The intra-assay and the inter-assay coefficients of variation (CV) for the standards were calculated to be within the range of $4 \cdot 20 \sim 11 \cdot 05 \%$ and $4 \cdot 14 \sim 9 \cdot 52 \%$, respectively. For the sensitivity of the assays, among the 175 patients, $146(83.4 \%)$ were positive by FEIA, compared with $111(63.4 \%)$ by bDNA assay $(p<0.01)$. For the specificity, all 13 controls were negative for both HCV RNA by bDNA and $\mathrm{HCV}$ core protein by FEIA.

In patients infected with HCV type 1 , the median serum HCV core protein level was 149 
TABLE I Clinical and virological characteristics of the 175 patients with chronic hepatitis $C$ virus infection and 13 controls

\begin{tabular}{|c|c|c|c|c|c|}
\hline \multirow[b]{2}{*}{ Characteristics } & \multicolumn{3}{|c|}{ Serologically defined HCV genotype } & \multirow[b]{2}{*}{ Indeterminate } & \multirow[b]{2}{*}{ Controls $\star$} \\
\hline & Type 1 & Type 2 & $\begin{array}{l}\text { Mixed type } \\
\text { (type } 1+2 \text { ) }\end{array}$ & & \\
\hline No of patients & $\mathrm{n}=129$ & $\mathrm{n}=31$ & $\mathrm{n}=3$ & $\mathrm{n}=12$ & $\mathrm{n}=13$ \\
\hline Sex (male:female) & $75: 54$ & $18: 13$ & $1: 2$ & $6: 6$ & $9: 4$ \\
\hline Age (year, mean (SD)) & $57 \cdot 3(12 \cdot 5)$ & $55 \cdot 3(12 \cdot 3)$ & $55 \cdot 0(10 \cdot 8)$ & $54 \cdot 2(13 \cdot 4)$ & $45.85(11.9)$ \\
\hline History of blood transfusion (\%) & $49(38.0)$ & $8(25.8)$ & $1(33 \cdot 3)$ & $4(33 \cdot 3)$ & \\
\hline Duration of infection $t$ (year) (mean (SD)) & $20 \cdot 7(14 \cdot 2)$ & $21 \cdot 6(13 \cdot 2)$ & 36 & $21.8(16 \cdot 0)$ & \\
\hline ALT (IU/I, mean (SD)) & $92 \cdot 3(90 \cdot 4)$ & $83.8(62 \cdot 0)$ & $79 \cdot 0(62 \cdot 0)$ & $72.4(48.4)$ & $53 \cdot 2(46 \cdot 0)$ \\
\hline Disease (CH:LC:HCC) & $61: 25: 43$ & $16: 7: 8$ & $2: 1: 0$ & $5: 4: 3$ & $5: 5: 3$ \\
\hline \multicolumn{6}{|c|}{ HCV core protein level (relative fluorescence intensity (RFI)) by fluorescent enzyme immunoassay (FEIA) } \\
\hline$\%$ positive & $86 \cdot 8$ & $71 \cdot 0$ & 100 & $75 \cdot 0$ & 0 \\
\hline median & 149 & 56 & 395 & 49 & $<20$ \\
\hline range & $<20 \sim 3708$ & $<20 \sim 1460$ & $157 \sim 594$ & $<20 \sim 1262$ & $<20$ \\
\hline \multicolumn{6}{|l|}{ HCV RNA level (million eq/ml) by bDNA } \\
\hline$\%$ positive & $71 \cdot 3$ & $38 \cdot 7$ & 100 & $33 \cdot 3$ & 0 \\
\hline median & $2 \cdot 90$ & $<1.05$ & $3 \cdot 88$ & $<0.35$ & $<0.35$ \\
\hline range & $<0.35 \sim 40.00$ & $<1.05 \sim 20.07$ & $1 \cdot 10 \sim 10 \cdot 00$ & $<0.35 \sim 3.10$ & $<0.35$ \\
\hline
\end{tabular}

${ }^{\star}$ Controls were seropositive for $\mathrm{HBsAg}$ and seronegative for anti-HCV by 2 nd EIA. †Duration of infection was estimated in patients with known history of blood transfusion only. $¥$ The values of HCV RNA level in patients with HCV type 2 infection were corrected by multiplying the value by 3 .

RFI (range: $<20$ to $3780 \mathrm{RFI}$ ) compared with 56 RFI (range: $<20$ to 1460 RFI, $p<0 \cdot 01$ ) in patients with HCV type 2 infection (Table I). The median serum HCV core protein level in the patients with HCV mixed type infection was $395 \mathrm{RFI}$ (range: 157 to $594 \mathrm{RFI}$ ), and for the indeterminate group, the median was 49 RFI (range: $<20$ to 1262). There was no correlation between serum HCV core protein level and the demographic (sex, age, history of transfusion) and biochemical (serum ALT) parameters. However, the median serum HCV core protein level in patients with $\mathrm{CH}$ was 227 RFI (range: $<20$ to 3708 RFI), compared with 94 RFI (range: $<20$ to $2070 \mathrm{RFI}, \mathrm{p}=\mathrm{NS}$ ) with LC, and 59 RFI (range: $<20$ to $1513 \mathrm{RFI}$, $\mathrm{p}=0.01$ ) with HCC.

For serum HCV RNA levels, the median levels for the patients with HCV type 1, 2, mixed type, and indeterminate type were 2.90 $\mathrm{Meq} / \mathrm{ml}$ (range: $<0.35$ to $40.00 \mathrm{Meq} / \mathrm{ml}$ ), $<1.05 \mathrm{Meq} / \mathrm{ml}$ (range: $<1.05$ (the converted cut off for HCV type 2) to $20.07 \mathrm{Meq} / \mathrm{ml}$ ), $3.88 \mathrm{Meq} / \mathrm{ml}$ (range: $1 \cdot 10$ to $10.00 \mathrm{Meq} / \mathrm{ml}$ ) and $<0.35 \mathrm{Meq} / \mathrm{ml}$ (range: $<0.35$ to $3.10 \mathrm{Meq} /$ $\mathrm{ml}$ ), respectively. There was a significant difference in serum HCV RNA levels between patients with $\mathrm{HCV}$ type 1 and 2 infection

TABLE II The reproducibility of HCV core protein assay by fluorescent enzyme immunoassay

\begin{tabular}{|c|c|c|c|}
\hline Number & Low level & Middle level & High level \\
\hline \multicolumn{4}{|l|}{ Intra-assay } \\
\hline 1 & $30 \cdot 5$ & $150 \cdot 2$ & $255 \cdot 2$ \\
\hline 2 & $30 \cdot 6$ & $143 \cdot 4$ & $228 \cdot 6$ \\
\hline 3 & $37 \cdot 0$ & 163.4 & 233.5 \\
\hline 4 & $26 \cdot 8$ & $162 \cdot 7$ & $249 \cdot 7$ \\
\hline 5 & $36 \cdot 4$ & $157 \cdot 3$ & 265.5 \\
\hline 6 & $31 \cdot 0$ & 161.4 & $283 \cdot 1$ \\
\hline 7 & $37 \cdot 5$ & $157 \cdot 9$ & $244 \cdot 8$ \\
\hline 8 & $35 \cdot 2$ & 155.9 & $238 \cdot 3$ \\
\hline 9 & $37 \cdot 5$ & $149 \cdot 3$ & $221 \cdot 4$ \\
\hline & $33 \cdot 1$ & $152 \cdot 0$ & $247 \cdot 6$ \\
\hline Mean (SD) & $33.56(3.71)$ & $155.35(6.53)$ & $246 \cdot 77(18 \cdot 19)$ \\
\hline CV (\%) & 11.05 & $4 \cdot 20$ & $7 \cdot 37$ \\
\hline \multicolumn{4}{|l|}{ Inter-assay } \\
\hline & 30.5 & $149 \cdot 8$ & $244 \cdot 5$ \\
\hline 2 & $33 \cdot 5$ & $150 \cdot 6$ & $250 \cdot 3$ \\
\hline 3 & $29 \cdot 7$ & $162 \cdot 8$ & $226 \cdot 5$ \\
\hline & $34 \cdot 8$ & 163.4 & $265 \cdot 0$ \\
\hline & $37 \cdot 4$ & $155 \cdot 7$ & 231.9 \\
\hline Mean (SD) & $33.18(3 \cdot 16)$ & $156.46(6.47)$ & $243.64(15 \cdot 27)$ \\
\hline CV (\%) & $9 \cdot 52$ & $4 \cdot 14$ & $6 \cdot 27$ \\
\hline
\end{tabular}

$\mathrm{CV}$ : coefficient of variation. $(\mathrm{p}=0.02)$ (Fig 1). In patients with HCV type 1 infection, $17(13.2 \%)$ were below the cut off value by FEIA, compared with $37(28 \cdot 7 \%)$ by bDNA $(\mathrm{p}<0.01)$ (Table III). In patients with HCV type 2 infection, nine $(29.0 \%)$ were below cut off by FEIA, compared with 19 $(61 \cdot 3 \%)$ by bDNA $(p=0.01)$.

Overall, there was a correlation between serum HCV core protein level by FEIA and serum HCV RNA level as determined by bDNA $(r=0.47, \mathrm{p}<0.01)$. When only patients with detectable $\mathrm{HCV}$ core protein and $\mathrm{HCV}$ RNA were analysed $(n=108$, type 1 : type 2 : mixed type: indeterminate=89: 12: 3: 4), there was a correlation between $\mathrm{HCV}$ core protein level and HCV RNA level in patients with $\mathrm{HCV}$ type 1 infection $(r=0.53$, $\mathrm{p}<0.01$ ), but no correlation was seen in patients with $\mathrm{HCV}$ type 2 infection $(r=0 \cdot 25$, $\mathrm{p}=0 \cdot 44$ ) (Fig 2).

Thirty seven of 84 patients with chronic active hepatitis $\mathrm{C}$ were subsequently treated with IFN. Eleven $(29 \cdot 7 \%)$ of them showed sustained response, and $26(70.3 \%)$ were nonresponders. There was no difference in sex (male: female $=4: 7 v 8: 18)$, age $(52 \cdot 1(9 \cdot 2) v$ $53 \cdot 1(10 \cdot 4))$, history of blood transfusion (2 of $11 v 8$ of 26) and pretreatment ALT (mean (SD)) $(90.9(45.6) \quad v \quad 120.7 \quad(65.5) \quad$ IU/l) between the patients showing sustained response and no response. However, the median $\mathrm{HCV}$ core protein level in the sustained response group (median: $36 \mathrm{RFI}$, range; $<20$ to $418 \mathrm{RFI}$ ) was significantly lower than the no response patients (338 RFI, range; 57 to $1580 \mathrm{RFI})(\mathrm{p}<0.01)$ (Fig 3). For the role of genotype in the response to IFN, two $(8 \cdot 7 \%)$ of the 23 patients with HCV type 1 developed sustained response, compared with seven $(63.6 \%)$ of 11 patients with $\mathrm{HCV}$ type 2 $(\mathrm{p}<0.01)$. To further analyse factors (sex, age, pretreatment ALT level, HCV genotype, serum HCV RNA level, and serum HCV core protein level) that predicted the subsequent response to IFN therapy, multivariate analysis was performed using a stepwise forward approach. Only HCV genotype $(p=0.001)$ and HCV core protein level $(p=0.026)$ were shown to be significant predicting factors by this analysis. 

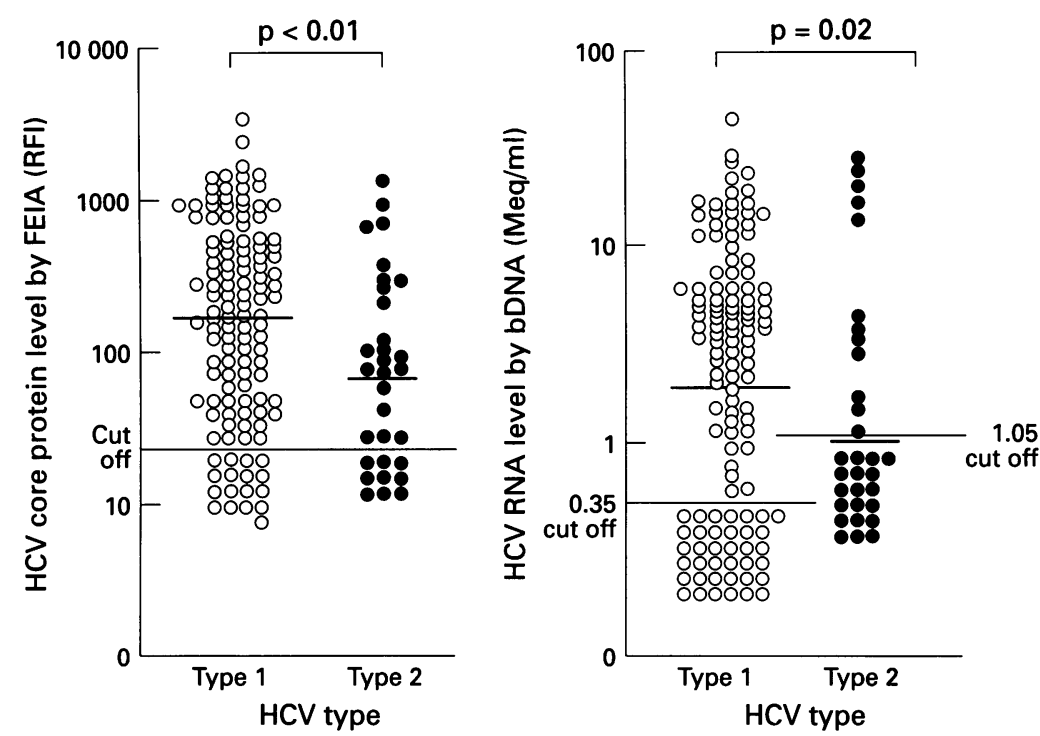

Figure 1: HCV core protein levels (left), and HCV RNA levels (right) in patients with $H C V$ types 1 and 2 infection. The median level of HCV core protein in patients with HCV type 1 was 149 relative fluorescence intensity (RFI) (range; <20 to 3708 RFI), compared with 56 RFI (range; $<20$ to 1460) in those with HCV type $2(p<0.01)$. As the values of serum HCV RNA level by bDNA assay were underestimated in patients with HCV type 2 infection, the values were multiplied by 3 as recommended..$^{22}$ The median levels of $H C V$ $R N A$ in patients with $H C V$ type 1 was 2.90 million eq/ml (Meq/ml) (range; $<0.35$ to 40.0), compared with $<1.05 \mathrm{Meq} / \mathrm{ml}$ in patients with HCV type 2 (range; $<1.05$ to 20.07 $\mathrm{Meq} / \mathrm{ml})(p<0.01)$. The solid bars represent the medians.

\section{Discussion}

This study illustrates four important points. Firstly, this FEIA assay was shown to be a sensitive assay with good reproducibility for the quantification of serum $\mathrm{HCV}$ core protein

TABLE III Relation between serum HCV core protein level as determined by FEIA and HCV RNA level as evaluated by $b D N A$ in patients with chronic $H C V$ types 1 and 2 infection

\begin{tabular}{lcrl}
\hline \multicolumn{4}{c}{ HCV core protein level by } \\
HCV RNA level & FELA & \\
\cline { 2 - 3 } by bDNA & $\leqslant 20 R F I$ & $>20$ RFI & \multicolumn{1}{c}{ Total } \\
\hline HCV type 1 infection & $(\mathrm{n}=129)$ & & \\
$\leqslant 0.35 \mathrm{Meq} / \mathrm{ml}$ & $15(11 \cdot 6)$ & $22(17 \cdot 1)$ & $37(28 \cdot 7)$ \\
$>0 \cdot 35 \mathrm{Meq} / \mathrm{ml}$ & $2(1 \cdot 6)$ & $90(69 \cdot 8)$ & $92(71 \cdot 4)$ \\
Total & $17(13 \cdot 2)$ & $112(86 \cdot 9)$ & $129(100)$ \\
HCV type 2 infection & $(\mathrm{n}=31)$ & & \\
$\leqslant 1.05 \mathrm{Meq} / \mathrm{ml}$ & $9(29 \cdot 0)$ & $10(32 \cdot 3)$ & $19(61 \cdot 3)$ \\
$>1.05 \mathrm{Meq} / \mathrm{ml}$ & $0(0)$ & $12(38 \cdot 7)$ & $12(38 \cdot 7)$ \\
Total & $9(29 \cdot 0)$ & $22(71 \cdot 0)$ & $31(100)$ \\
\hline
\end{tabular}

Figures in parentheses are percentages. irrespective of HCV genotypes. Secondly, there was a correlation between serum $\mathrm{HCV}$ core protein level and HCV RNA level as determined by FEIA and bDNA, respectively, in patients with HCV type 1 but not in type 2 infection. Thirdly, patients with HCV type 2 infection had lower level of serum $\mathrm{HCV}$ core protein compared with HCV type 1. Finally, low serum HCV core protein level is also an indicator of a subsequent favourable response to IFN.

The finding that this FEIA assay is a sensitive assay for patients with different $\mathrm{HCV}$ genotypes emphasise the usefulness of this assay. In an analysis of the conservation of the HCV core amino acid sequences from all known isolates available through GenBanks, the region recognised by the monoclonal antibodies (amino acid 21-60) was shown to be highly conserved (data not shown).

There are a few possible explanations to account for the lack of correlation between serum HCV core protein and HCV RNA in patients infected with HCV type 2. Firstly, the number of patients with HCV type 2 infection was small in this study and may miss a weak correlation. Secondly, the number of HCV core proteins in HCV type 2 may be more variable or low compared with $\mathrm{HCV}$ type 1 . As most other viruses contain a comparatively stable number of core molecules per viral particle, it is fairly safe to assume that this is the case for $\mathrm{HCV}$, arguing that the quantification of HCV RNA by bDNA version 1.0 on $\mathrm{HCV}$ type 2 may be more variable than HCV type 1. Further studies based on large number of patients comparing FEIA and bDNA version 2.0 are required to further define the concordance between these two assays.

The finding that serum HCV core protein level in patients with HCV type 2 infection was lower than those with HCV type 1 is also in accord with previous studies using competitive RT-PCR or bDNA assays, which also showed lower serum HCV RNA level in patients with HCV type 2 compared with type $1 .{ }^{101118}$ The recent finding that bDNA version 1.0 assay underestimates HCV RNA derived from $\mathrm{HCV}$

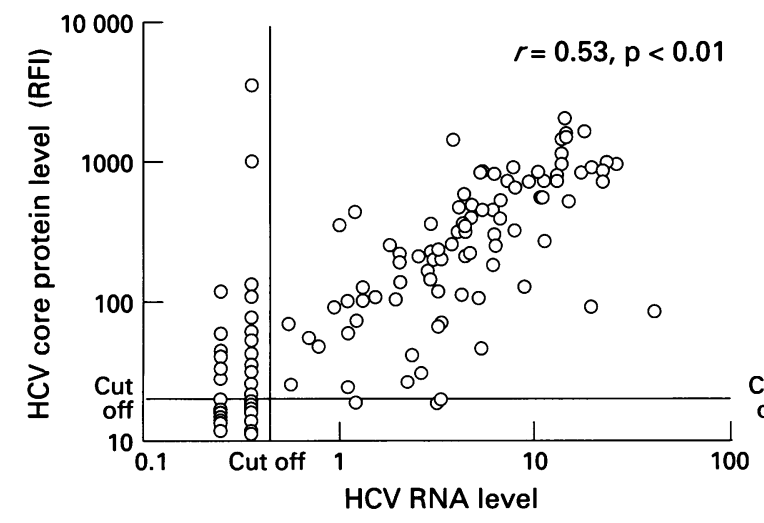

HCV type 1 infection

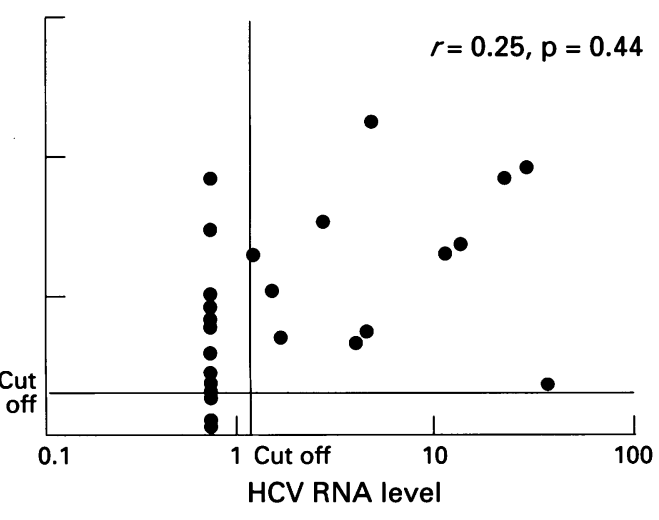

HCV type 2 infection

Figure 2: The correlation between serum HCV core protein level by FELA and HCV RNA level by bDNA in patients with $H C V$ types 1 (left) and type 2 (right) infection. In all patients, there was a significant correlation between serum HCV core protein and HCV RNA levels $(n=175, \mathrm{r}=0.48, p<0.01)$. When only patients with detectable $H C V$ core protein and $H C V$ $R N A$ were analysed, HCV core protein level correlated to $H C V R N A$ level in patients with $H C V$ type 1 infection ( $n=89$, $\mathrm{r}=0.53, p<0 \cdot 01)$, but not in patients with HCV type 2 infection $(n=12, \mathrm{r}=0.25, p=0.44)$. 


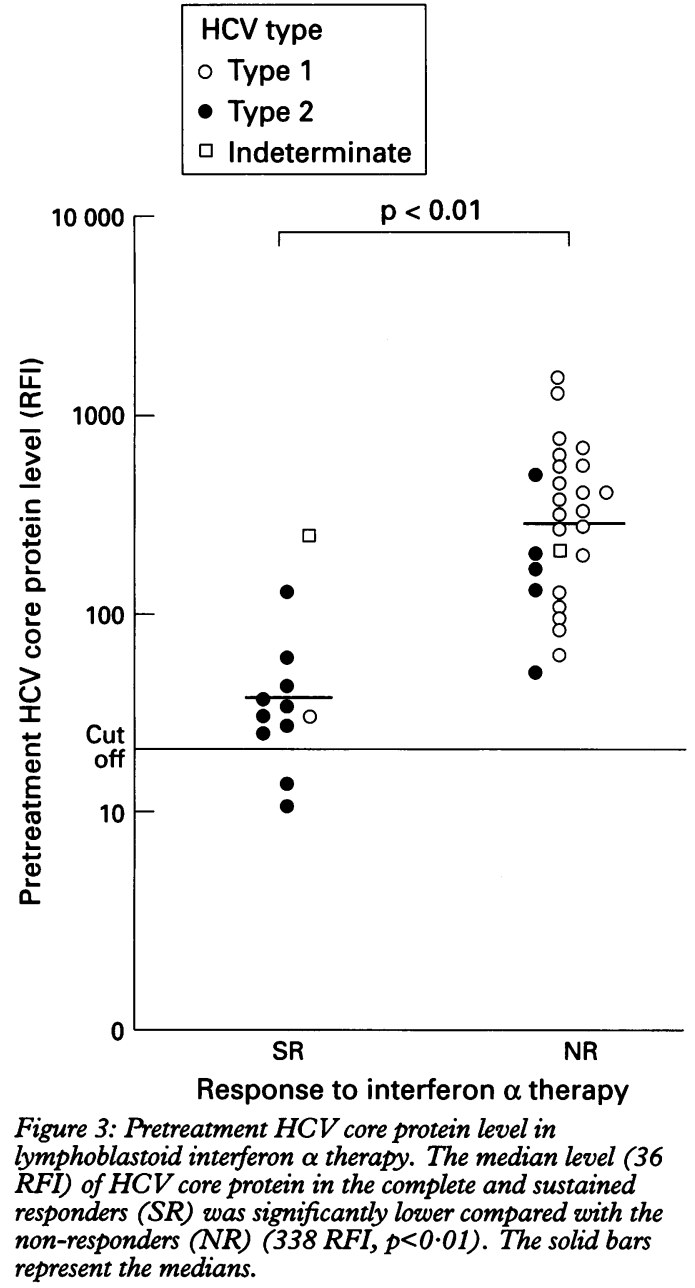

type 2 and 3 illustrates the difficulties in developing a reliable assay for the quantification of a viraemia, ${ }^{12}$ given the pronounced genetic heterogeneous nature of the $\mathrm{HCV}$ genome. bDNA assay version $2 \cdot 0$ was designed to tackle these problems. As this FEIA is using monoclonal antibodies that recognised highly conserved epitopes across HCV type 1 and 2, it is likely that this assay will also be very useful in quantification of $\mathrm{HCV}$ viraemia. A proper head to head comparison between two assays in the future may resolve this issue.

It was reported that low pretreatment $\mathrm{HCV}$ RNA level is a good predictor of a subsequent favourable response to IFN therapy. ${ }^{811}$ Our finding of a significant difference in serum HCV core protein level between patients showing different subsequent response to IFN suggests that measuring serum HCV core protein level is a good alternative.

The authors wish to express gratitude to Dr Osamu Yanagihara for his kind assistance. M Mizokami was supported by grants Hepatitis Research Foundation of Japan; and a grant from the
Ministry of Education, Science, and Culture of Japan. M Kohara was supported by a grant in aid for Specially Promoted Research on Viral Diseases from the Tokyo Metropolitan Government; a grant from the Ministry of Education, Science and Culture of Japan; a grant from the Ministry of Health and Welfare of Japan. J Y-N Lau was supported in part by the DSRD-15, DSR-RDA-1-15 grants from the Division of Sponsored Research, University of Florida, Gainesville, FL, USA; American Liver Foundation Hans Popper Liver Scholar Award, Glaxo Institute of Digestive Health Clinical Investigator Award.

1 Choo Q-L, Kuo G, Weiner AJ, Overby LR, Bradley DW, Houghton $M$. Isolation of a cDNA clone derived from a blood-borne non-A, non-B viral hepatitis genome. Science 1989; 244: 1-3.

2 Choo Q-L, Richman $\mathrm{KH}$, Han JH, Berger $\mathrm{K}$, Lee C, Dong $\mathrm{C}$, et al. Genetic organization and diversity of the hepatitis C virus. Proc Natl Acad Sci USA 1991; 88. 2451-5.

3 Kaito M, Watanabe S, Tsukiyama-Kohara K, Yamaguchi K, Kobayashi Y, Konishi M, et al. Hepatitis C virus particle detected by immunoelectron microscopic study. $\mathcal{F}$ Gen Virol 1994; 75: 1755-60.

4 Kuo G, Choo Q-L, Alter HJ, Gitnick GL, Redeker AG, Purcel RH, et al. An assay for circulating antibodies to a major etiological virus of human non-A, non-B hepatitis. Science 1989; 244: 362-4.

5 Van der Poel VCL, Cuypers HTM, Reesink HW, Weiner AJ, Quan S, DiNello R, et al. Confirmation of hepatitis $C$ virus infection by new four-antigen recombinant immunoblot assay. Lancet 1991; 337: 317-9.

6 Okamoto H, Okada S, Sugiyama Y, Tanaka T, Sugai Y, Akahane $Y$, et al. Detection of hepatitis $C$ virus RNA by a two-stage polymerase chain reaction with two pairs of primers deduced from the 5'-noncoding region. $\mathcal{f p}_{p} \mathcal{f} \operatorname{Exp}$ Med 1990; 60: 215-22.

7 Lau JYN, Davis GL, Knniffen J, Qian KP, Urdea MS, Chan $\mathrm{CS}$, et al. Significance of serum hepatitis C virus RNA levels in chronic hepatitis C. Lancet 1993; 341: 1501-4.

8 Kaneko S, Murakami S, Unoura $M$, Kobayashi K. Quantitation of hepatitis C virus RNA by competitive polymerase chain reaction. f Med Virol 1992; 37: 278-82.

9 Kato N, Yokosuka O, Hosoda K, Ito Y, Ohto M, Omata $M$. Quantification of hepatitis $C$ virus by competitive reverse transcription-polymerase chain competitive reverse transcription-polymerase chain reaction: increase of the virus
Hepatology 1993; 18: 16-20.

10 Yoshioka K, Kakumu S, Wakita T, Itoh Y, Takayanagi M, Higashi $\mathrm{Y}$, et al. Detection of hepatitis $\mathrm{C}$ virus by polymerase chain reaction and response to interferon alfa therapy: relationship to genotypes of hepatitis $\mathrm{C}$ virus. Hepatology 1992; 16: 293-9.

11 Orito E, Mizokami M, Nakano T, Terashima H, Nojiri $O$ Sakakibara $\mathrm{K}$, et al. Serum hepatitis $\mathrm{C}$ virus RNA leve as a predictor of subsequent response to interferon-a therapy in Japanese patients with chronic hepatitis C. $\mathcal{F}$ Med Virol 1994; 44: 410-4.

12 Collins ML, Zayati C, Detmer J, Daly B, Kolberg JA, Cha TA, et al. Preparation and characterization of RNA TA, et al. Preparation and characterization of RNA standards for use in quantitative branched DNA
hybridization assays. Anal Biochem 1995; 226: 120-9.

13 Lau JYN, Simmonds P, Urdea MS. Implications of variations of "conserved" regions of hepatitis $C$ virus genome. Lancet 1995; 346: 425-6.

14 Tanaka T, Lau JYN, Mizokami M, Orito E, Tanaka E, Koyosawa $\mathrm{K}$, et al. Simple fluorescent enzyme immunoassay for detection and quantification of hepatitis $\mathrm{C}$ viremia. F Hepatol 1995; 23: 742-5.

15 Davis GL, Lau JYN, Urdea MS, Neuwald PD, Wilber JC, Lindsay $\mathrm{K}$, et al. Quantitative detection of hepatitis C virus RNA with a solid-phase signal amplification method: definition of optimal conditions for specimen collection and clinical application in interferon-treated patients. Hepatology 1994; 19: 1337-41.

16 Tanaka $\mathrm{T}$, Tsukiyama-Kohara $\mathrm{K}$, Yamaguchi $\mathrm{K}$, Yagi $\mathrm{S}$, Tanaka S, Hasegawa A, et al. Significance of specific antibody assay for genotyping of hepatatis $C$ virus. Hepatology 1994; 19: 1347-53.

17 Simmonds P, Alberti A, Alter HJ, Bonino F, Bradley DW, Brechot C, et al. A proposed system for the nomenclature of hepatitis C viral genotypes. Hepatology 1994; 19: 1321-4.

18 Lau JYN, Mizokami M, Kolberg JA, Davis GL, Prescott LE, Ohno $\mathrm{T}$, et al. Application of six hepatitis $\mathrm{C}$ virus genotyping systems to sera from chronic hepatitis C patients in the United States. F Infect Dis 1995; 171 281-9. 